\title{
Защита картофеля при хранении
}

\section{В.Н. Зейрук, Г.Л. Белов, С.В. Мальцев, О.В. Абашкин, Д.В. Абросимов}

Приведены данные двухлетнего исследования по поиску эффективных препаратов для осеннего протравливания семенного картофеля. Наилучший результат получен при обработке клубней препаратом Максим (0,2 л/т) и при совместном использовании препаратов Картофин и Силиплант (30 мл/т + 7,5 г/т). При этом биологическая эффективность составила соответственно $46,6 \%$ и 37,2\%. Общие потери снизились на 7,6\% и 6,3\%.

Ключевые слова: картофель(Solanum tuberosum L.), защита, хранение, болезни, потери, препараты, биологическая эффективность.

Д ля сокращения потерь при хранении картофеля необходим комплекс защитных мероприятий, начиная с подготовки почвы и семенного материала к посадке, затем при уходе за растениями, в периоды предуборочный, уборочный, послеуборочной доработки клубней и непосредственно при хранении. В этот комплекс входят селекционно-семеноводческие, организационно-хозяйственные, агротехнические, биологические, физиолого-биохимические, физические и химические мероприятия. Центральное место среди этих мероприятий сегодня занимает химический метод защиты. Однако он не всегда приносит высокий эффект. Поэтому сейчас актуальна разработка системы мероприятий, снижающих пестицидную нагрузку на агробиоценоз. В связи с этим особую актуальность приобретают исследования новых технологий и препаратов по защите заложенной на хранение продукции $[1,2,3]$.

Цель исследований - определить биологическую эффективность осеннего протравливания семенного картофеля химическими, биологическими препаратами и агрохимиката- ми в период закладки на постоянное хранение.

Опыт закладывали на экспериментальной базе ФГБНУ ВНИИКХ имени А.Г. Лорха «Ильинское» в Домодедовском районе Московской области в соответствии со стандартными методиками [4]. Хранилище навального типа с высотой насыпи 3 м, в котором установлены энергосберегающие вентиляторы с регулируемым числом оборотов в зависимости от периода хранения и состояния картофеля в насыпи.

Опыты проводили с клубнями среднепозднего сорта Никулинский в 2017-2018 годах. Все опытные образцы закладывали в насыпь картофеля на глубину 0,4-0,5 м и хранили с ноября по июнь месяц. После закладки образцов в картофелехранилище температура составляла в ноябре $10^{\circ} \mathrm{C}$, с декабря по март от 1,5 до $4^{\circ} \mathrm{C}$, в апреле - от 4 до $6^{\circ} \mathrm{C}$, а в остальной период $-5-7{ }^{\circ} \mathrm{C}$. Относительная влажность воздуха - 85,0-95,0\%.

Схема опыта:

1. Контроль - обработка водой, 10 л/т;

2. Максим, КС, 0,2 л/т (эталон);

3. Картофин, 7,5 г/т;

4. Силиплант, 30 мл/т;
5. Силиплант + Картофин, 30 мл/т $+7,5$ г/т;

Расход рабочей жидкости - 10 л/т.

Повторность каждого варианта опыта четырехкратная, масса клубней в образце - 5 кг.

В опыте использовали препарат Картофин, полученный путем микробиологического синтеза на основе культуры Bacillus subtilis штамм И512/23. Действующее начало препарата - живые споры и комплекс антибиотиков, выделяемых бактерией. Предназначен для борьбы с бактериальными и грибными инфекциями картофеля.

Силиплант - это новое кремнийсодержащее удобрение, в состав которого, кроме кремния и калия (13-21 мг/л), входят в легкодоступной для растений хелатной форме микроэлементы (г/л): $\mathrm{Fe}-$ 0,44-0,54; $\mathrm{Mg}$ - 0,12-0,13; $\mathrm{Cu}$ $0,09-0,27 ; \mathrm{Zn}$ - 0,74-0,87; Mn 0,32-0,37; Mo - 0,06-0,074; Co 0,02-0,024; В - 0,094-0,112. При применении этого препарата клубни меньше прорастают, тормозится развитие болезней [5].

Оценку эффективности изучаемых препаратов проводили по следующим показателям: распространенность основных гнилей клубней при хранении по счету и по массе, согласно ГОСТ 33996-2016 «Картофель семенной. Технические условия и методы определения качества» [6],биологическая эффективность, которую рассчитывали по формуле:

\section{$\boldsymbol{\vartheta}_{\sigma}=\mathbf{1 0 0}(\mathrm{a}-\mathrm{B}) / \mathrm{a}$}

где, $\boldsymbol{Э}_{6}$ - биологическая эффективность, \%; а и в-соответственно показатели средней пораженности клубней картофеля в контроле и на обработанном варианте; убыль массы по показателям: абсолютная гниль, технические отходы, естественная убыль, согласно «Технологии хранения картофеля» [7].

Статистическую обработку полученных результатов проводили методом дисперсионного анализа по Б.А. Доспехову [8]

\section{Таблица 1. Пораженность клубней картофеля болезнями в конце хранения, 2017-2018 годы}

\begin{tabular}{|c|c|c|c|c|c|c|}
\hline \multirow[b]{2}{*}{ Вариант } & \multicolumn{5}{|c|}{ Поражено клубней, \% } & \multirow{2}{*}{$\begin{array}{c}\text { Биологическая } \\
\text { эффективность, } \\
\%\end{array}$} \\
\hline & всего & $\begin{array}{c}\text { парша } \\
\text { обыкновенная }\end{array}$ & ризоктониоз & сухая гниль & мокрая гниль & \\
\hline Контроль & 12,9 & 2,3 & 3,9 & 6,0 & 0,7 & - \\
\hline Максим & 6,9 & 2,1 & 1,4 & 3,3 & 0,1 & 46,6 \\
\hline Картофин & 10,3 & 2,8 & 2,9 & 4,6 & 0,0 & 20,2 \\
\hline Силиплант & 9,8 & 2,2 & 2,6 & 4,9 & 0,1 & 24,1 \\
\hline Силиплант +Картофин & 8,1 & 2,7 & 2,4 & 2,9 & 0,1 & 37,2 \\
\hline
\end{tabular}


Таблица 2. Потери урожая картофеля после осеннего протравливания клубней, 2017-2018 годы

\begin{tabular}{|l|c|c|c|c|c|}
\multicolumn{1}{|c|}{ Вариант } & \multicolumn{3}{|c|}{ Потери, \% } \\
\cline { 2 - 5 } & всего & абсолютная гниль & технический отход & естественная убыль массы & ростки \\
\hline Контроль & 30,6 & 0,8 & 5,8 & 12,8 \\
\hline Максим & 23,0 & 0,4 & 3,1 & 8,4 \\
\hline Картофин & 26,1 & 0,2 & 4,7 & 9,6 \\
\hline Силиплант & 25,0 & 0,1 & 4,5 & 9,3 \\
\hline Силиплант + Картофин & 24,3 & 0,6 & 2,1 & 11,6 \\
\hline НСР & 6,2 & 0,14 & 1,15 & 8,8 \\
\hline
\end{tabular}

Перед обработкой и закладкой картофеля на хранение с целью определения фитопатологического состояния клубней проводили клубневой анализ. Учеты поражения перед обработкой препаратами показал, что общее количество больных клубней составило 7,8\%, из них паршой обыкновенной было поражено $2,8 \%$, ризоктониозом - 3,6\%, сухой гнилью - 1,7\%.

Результаты фитопатологического анализа, проведенного весной, после длительного хранения, показали, что обработка клубней всеми изучаемыми препаратами оказала положительное влияние на уменьшение количества больного картофеля и сократила потери урожая по сравнению с контрольным вариантом (табл.1, 2).

Так, биологическая эффективность обработки клубней картофеля фунгицидом Максим составила 46,6\%. Потери по массе клубней составили 23,0\%, что ниже контроля на 7,6\%. Потери были в основном за счет естественной убыли массы $(8,4 \%)$ и ростков $(11,1 \%)$.

Биологические препараты Картофин и Силиплант показали более низкую эффективность. Так, количество пораженных клубней снизилась на 4,5\% и 5,6\% соответственно. Биологическая эффективность составила 20,2 и 24,1\%, что ниже химического эталона на 26,4-22,5\%.

Совместное применение биопрепарата и агрохимиката оказалось более эффективным, чем их раздельное применение, но уступало химическому эталону. Так, биологическая эффективность этого комплекса составила $37,2 \%$, что ниже применения Максима на 9,4\%. Однако, это позволило снизить общие потери урожая на 6,3\% по сравнению с контролем.

Наши данные согласуются с результатами исследований белорусских ученых [9]. По их данным биологическая эффективность против сухой фузариозной гнили антагониста
Bacillus subtilis 26 Д при протравливании семенного материала картофеля закладываемого на хранение с нормой расхода 1 л/т несколько уступает эталонному препарату Максим, КС (65,0\% против 80,0\%).

Таким образом, применение биологических препаратов Картофин, Силиплант и их совместное использование незначительно, но уступало по эффективности химическому эталону. Биологическая эффективность биопрепаратов составила 20,2-37,2\%, а химического препарата Максим - 46,6\%. Осенняя обработка клубней картофеля изученными биологическими препаратами позволила снизить общие потери при длительном хранении на 4,56,3\% (в зависимости от препарата), главным образом за счет снижения естественной убыли массы.

\section{Библиографический список}

1.Зейрук В.Н. Разработка и совершенствование технологического процесса защиты и хранения картофеля в Центральном регионе РФ: автореф... д-ра с.- х. наук. М., 2015. 44 c.

2.Зейрук В.Н. и др. Влияние обработки клубней картофеля защитно-стимулирующими препаратами на потери при хранении // Картофелеводство: материалы научно-практической конференции «Современные технологии производства, хранения и переработки картофеля», (1-3 августа, 2017 года). М.: ФГБНУ ВНИИКХ, 2017. С. 292-300.

3.Бородай В.В., Даниловка Т.В., Колтунов В.А. Эффективность биопрепаратов Планриз, Диазовит и Фосфоэнтерин в защите от фитопатогенов при выращивании и хранении картофеля / Картофелеводство: сбор. научн. тр. Минск, 2012. Т. 20. С. 102-111.

4.Методика исследований по культуре картофеля. М. НИИКХ, 1967. 264 с.

5.Дорожкина Л.А., Караваев В.А., Гунар Л.Э., Поддымкина Л.М. Циркон и Силиплант -антистрессовые и рострегулирующие препараты // Плодородие. 2016. № 2 (89). С. 13-15.

6.Межгосударственный стандарт ГОСт 33996-2016 Картофель семенной. Технические условия и методы определения качества. М.: Стандартинформ, 2016. 41 c.

7.Хранение картофеля / К. А. Пшеченков, В.Н.Зейрук, С. Н. Еланский и др. М.: Агроспас, 2016. 144 с.

8.Доспехов Б. А. Методика полевого опыта (с основами статистической обработки результатов исследований). М.: Агропромиздат, 1985. 352 с.

9.Абакшонок В.С., Бусько И.И. Биологическая эффективность препарата Bacillus subtilis 26 Д против клубневых гнилей картофеля при хранении / Картофелеводство: сбор. научн. тр. Минск, 2012. Т. 20. C. $95-101$

\section{Об авторах \\ Зейрук Владимир \\ Николаевич, доктор с. - х. наук, зав. лабораторией защиты растений. \\ E-mail: vzeyruk@mail.ru}

Белов Григорий Леонидович, канд. биол. наук, с.н. с. лаборатории защиты

\section{Мальцев Станислав}

Владимирович, канд. С. - х. наук, с.н.с. группы по хранению

\section{Абашкин Олег}

Владимирович, начальник опорнопроизводственной базы

Абросимов Дмитрий Васильевич, канд. с. - х. наук, зав. лабораторией оригинального семеноводства. ФГБНУ «Всероссийский научно-исследовательский институт картофельного хозяйства имени А.Г. Лорха»

Protection of potatoes during storage V.N. Zeyruk, DSc, head of laboratory plant protection.E-mail: vzeyruk@mail.ru

G.L. Belov, PhD, senior research fellow laboratory plant protection.

S.V. Maltsev, PhD, senior research fellow.

O.V. Abashkin, head of support and production base

D.V. Abrosimov, PhD, senior research

fellow, head of laboratory

FSBSI All-Russian Scientific Research Institute of Potato Farm named after

\section{A. G. Lorkh}

Summary. The data of a two-year study on the search for effective drugs for autumn seed potatoes etching are presented. The best result was obtained when processing tubers Maximum (0,2 $l / t$ ) and the joint use of Kartofin and Siliplant (30 ml/t $+7,5 \mathrm{~g} / \mathrm{t}$ ). The biological efficiency was $46.6 \%$ and $37.2 \%$, respectively. Total losses decreased by $7.6 \%$ and $6.3 \%$.

Keywords: potato (Solanum tuberosum L.), protection, storage, diseases, losses, preparations, biological efficiency. 